\title{
TINJAUAN ATAS PERLAKUAN AKUNTANSI LINGKUNGAN PADA RUMAH SAKIT UMUM DAERAH (RSUD) BAHTERAMAS
}

\author{
Oleh \\ Muntu Abdullah ${ }^{1}$, Erwin Hadisantoso ${ }^{2}$, Eka Trisaktiani ${ }^{3}$ \\ Jurusan Akuntansi Fakultas Ekonomi dan Bisnis Universitas Halu Oleo Kendari \\ Sulawesi Tenggara
}

\begin{abstract}
ABSTRAK
Penelitian ini bertujuan untuk mengetahui bagaimana perlakuan akuntansi lingkungan terhadap pengelolahan limbah pada RSUD Bahteramas menyangkut Identifikasi, pengukuran, pengakuan, penyajian, dan pengungkapannya serta bagaimana proses pengelolaan limbah dan tanggung jawab sosial di RSUD Bahteramas. Metode penggumpulan data menggunakan dokumentasi, studi kepustakaan dan wawancara. Analisis data menggunakan metode analisis deskriptif.

Hasil penelitian ini menunjukan bahwa RSUD Bahteramas dalam mengidentifikasi akuntansi biaya lingkungannya, diakui sebagai komponen beban barang dan jasa, beban pemeliharaan dan belanja modal yang digolongkan ke dalam akun belanja operasional. Penyajiannya bersama-sama dengan biaya-biaya yang sejenis dalam laporan keuangan. Dan pengungkapannya masuk ke dalam catatan atas laporan keuangan RSUD Bahteramas. Sedangkan untuk pengelolaan limbahnya, RSUD Bahteramas sudah mengelola limbahnya dengan baik sehingga dapat dikatakan bahwa RSUD Bahteramas sudah melakukan tanggung jawab sosial terhadap lingkungan di sekitarnya. Kesimpulan dari penelitian ini menunjukan bahwa RSUD Bahteramas belum menyajikan laporan khusus mengenai akuntansi lingkungannya secara lebih rinci di dalam laporan keuangan rumah sakit. RSUD Bahteramas sudah melakukan tanggung jawab sosialnya sebagai organisasi yang kegiatan operasionalnya menghasilkan limbah yang berbahaya
\end{abstract}

Kata Kunci: Akuntansi lingkungan, Aktivitas Lingkungan, Biaya Lingkungan dan

Perlakuan Akuntansi.

\section{ABSTRACT}

The aims of this study was to determine how the environmental accounting treatment of waste management in Bahteramas Regional Hospital is related to the identification, measurement, recognition, presentation and disclosure, as well as how the process of waste management and social responsibility in Bahteramas Regional Hospital. Documentatation,literature study and interview are used in the data collection method.Wherein, descriptive analysis method is used in data analysis.

The results of this study indicate that the Bahteramas Regional Hospital identifies the environmental costs accounting, namely goods and services expenses, maintenance expenses and capital expenditures that are classified into operational expenditure accounts. The presentation was together with similar costs in the financial statements. And the disclosure was included in notes of the to the Bahteramas Regional Hospital financial statements. As for waste management, Bahteramas Regional Hospital has managed its waste well so it can be said that the Bahteramas Regional Hospital has carried out social responsibility to the surrounding environment. It is concluded that the Bahteramas Regional Hospital has not presented a specific report on environmental accounting with complete detail in the hospital's financial statements. Bahteramas Regional Hospital has carried out its social responsibility as an organization whose operational activities produce hazardous waste. 
Keywords: Environmental Accounting, Environmental Activities, Eenvironmental Costs, and Accounting Treatment.

\section{PENDAHULUAN}

Pada era globalisasi saat ini isu tentang kerusakan alam dan pemanasan global menjadi perhatian yang serius. Bumi yang sudah tidak sehat lagi menunjukkan berbagai macam gejala, salah satu dampak dari kerusakan lingkungan seperti kondisi cuaca yang tidak normal dan teratur, bencana alam di berbagai tempat, dan semacamnya. Perusahaan dianggap sebagai salah satu penyebab kerusakan lingkungan, karena perusahaanperusahaan cenderung mencari keuntungan yang sebesar-besarnya tanpa memperhatikan dampaknya terhadap lingkungan.Pengelolaan lingkungan menjadi wujud tanggungjawab perusahaan terhadap lingkungan sekitar. Aktivitas yang timbul dari pengelolaan lingkungana akan memunculkan biaya-biaya lingkungan. Perusahaan perlu mengukur biaya lingkungan dari aktivitas pengelolaan lingkungan. Biaya lingkungan merupakan dampak, baik moneter maupun nonmoneter sebagai akibat dari kegiatan yang mempengaruhi kualitas lingkungan (Ikhsan, 2009:82).

Akuntansi lingkungan merupakan perkembangan dari akuntansi sosial sebagai bentuk tanggungjawab sosial pada bidang ilmu akuntansi yang berfungsi untuk mengidentifikasi, mengakui, mengukur, menyajikan, dan mengungkapkan akuntansi lingkungan (Islamey,2016). Perlakuan terhadap masalah penanganan limbah hasil operasional perusahaan ini menjadi sangat penting dalam pengendali pertanggungjawaban perusahaan terhadap lingkungannya. Keuntungan yang dicapai perusahaan dari penerapan akuntansi lingkungan juga bertujuan untuk mengetahui seberapa besar biaya lingkungan yang dikeluarkan dalam mengelolah limbah tersebut dengan menggunakan sistem akuntansi sehingga dapat meminimalkan biaya yang dikeluarkan, dapat mengontrol tanggung jawab perusahaan dalam menjaga lingkungan sekitarnya (Ikhsan, 2009: 21).

Penerapan Green Hospital di tahun 2013 menjadi isu yang marak diperbincangkan. Konsep rumah sakit yang berwawasan lingkungan di rumah sakit lebih diarahkan pada penggunaan air yang efektif dan efisien, penggunaan energi listrik yang efisien, serta pengelolaan limbah cair yang berwawasan lingkungan. Di sisi lain, Green Hospital harus memperhatikan adanya pengelolaan limbah padat (sampah) yang baik dan berwawasan lingkungan. Tindakan Rumah sakit sebagai upaya pelestarian lingkungan rumah sakit agar lebih baik, sehat dan nyaman, dapat dilakukan melalui penyediaan ruang terbuka hijau dan menjadikan rumah sakit area bebas rokok. Hal ini dapat tercipta melalui manajemen yang berwawasan lingkungan.

Rumah sakit merupakan instansi pemerintahan yang bergerak dibidang jasa pelayanan kesehatan masyarakat. Sesuai dengan Peraturan Menteri Kesehatan Republik Indonesia No.340/MENKES/PER/III/2010 yaitu : "Rumah sakit adalah institusi pelayanan kesehatan yang menyelenggarakan pelayanan kesehatan perorangan secara paripurna yang menyediakan pelayanan rawat inap, rawat jalan dan gawat darurat". Berdasarkan pengertian di atas, rumah sakit melakukan beberapa jenis pelayanan diantaranya pelayanan medik, pelayanan penunjang medik, pelayanan perawatan, pelayanan rehabilitasi, pencegahan dan peningkatan kesehatan, sebagai tempat pendidikan dan atau pelatihan medik dan para medik, sebagai tempat penelitian dan pengembangan ilmu dan teknologi bidang kesehatan. Serta untuk menghindari risiko dan gangguan kesehatan sebagaimana yang dimaksud, sehingga perlu adanya penyelenggaraan kesehatan lingkungan rumah sakit sesuai dengan persyaratan kesehatan.

Adanya masalah lingkungan tersebut pemerintah menerapkan peraturan terkait lingkungan hidup antara lain undang-undang No. 23 Tahun 1997 tentang Pengelolahan 
Lingkungan Hidup, Permenkes Nomo 1204/MENKES/SK/ X/2004 tentang Persyaratan Kesehatan Lingkungan Rumah Sakit. Jakarta: Depkes RI, Peraturan Pemerintah No. 27 Tahun 1999 tentang AMDAL. Peraturan tersebut mengikat semua pihak jika terjadi pelanggaran dalam ketentuan peraturan tersebut akan sanksi pidana maupun perdata. Dalam hal ini, masyarakat mempunyai hak dalam pengawasan dikarenakan masyarakat memiliki hak atas lingkungan yang baik dan bersih.

Rumah Sakit Umum Daerah (RSUD) Bahteramas menghasilkan limbah B3 (bahan berbahaya dan beracun) yang dapat membahayakan lingkungan, untuk mengatasi hal tersebut pihak rumah sakit Bahteramas telah bekerja sama dengan PT Mitra Hijau Asia Cabang Kendari dalam hal penanganan limbah B3 yang di hasilkan oleh rumah sakit, karena pihak rumah sakit Bahteramas belum mampu mengelolah limbah B3 yang di hasilkan secara mandiri, maka pihak rumah sakit harus mengirim limbah B3 yang di hasil ke kota Surabaya untuk kemudian diolah. Pihak rumah sakit juga mengeluarkan biaya-biaya lingkungan untuk melakukan pengelolaan limbah cair dengan Instalasi Pengelolaan Air Limbah (IPAL), serta biaya lainnya untuk mengurangi tingkat pencemaran limbah di lingkungan Rumah Sakit Umum Daerah (RSUD) Bahteramas.

Berdasarkan Laporan Keuangan tahun 2018, kita dapat melihat jumlah anggaran yang dikeluarkan Rumah Sakit Umum Daerah (RSUD) Bahteramas dalam pengelolaan sebagai mana di sajikan dalam tabel.1.1.

Tabel 1. Laporan Realisasi Anggaran

\begin{tabular}{|c|c|c|c|c|c|}
\hline Keterangan & \multicolumn{2}{|c|}{ Anggaran } & \multicolumn{2}{|c|}{ Realisasi } & $\%$ \\
\hline Belanja Jasa Service dan Suku Cadang & $\mathrm{Rp}$ & 200.000 .000 & $\mathrm{Rp}$ & 71.496 .116 & 35,75 \\
\hline Belanja Cleaning Service & $\mathrm{Rp}$ & 2.640 .000 .000 & $\mathrm{Rp}$ & 2.551 .586 .400 & 96,65 \\
\hline Belanja Linen & $\mathrm{Rp}$ & 300.000 & $\mathrm{Rp}$ & 149.970 & 49,90 \\
\hline $\begin{array}{l}\text { Belan Pemeriksaan Penunjang Luar } \\
\text { rumah Sakit }\end{array}$ & RP & 600.000 .000 & $\mathrm{Rp}$ & 386.978 .000 & 64,50 \\
\hline Belanja Pemeriksaan Baku Mutu Air & $\mathrm{Rp}$ & 21.000 .000 & $\mathrm{Rp}$ & 9.730 .000 & 44,63 \\
\hline Belanja Air & $\mathrm{Rp}$ & 1.920 .000 & $\mathrm{Rp}$ & 1.509 .284 & 78,61 \\
\hline Belanja Pengangkutan Sampah & $\mathrm{Rp}$ & 84.000 .000 & $\mathrm{Rp}$ & 54.000 .000 & 64,29 \\
\hline Belanja Pemusnahan Limbah Infeksius & $\mathrm{Rp}$ & 550.000 .000 & $\mathrm{Rp}$ & 542.424 .168 & 98,62 \\
\hline Belanja Pemeliharaan AC & $\mathrm{Rp}$ & 458.000 .000 & $\mathrm{Rp}$ & 455.761 .500 & 99,51 \\
\hline Biaya Pemeliharaan Jalan & $\mathrm{Rp}$ & 100.000 .000 & $\mathrm{Rp}$ & 49.536 .025 & 49,54 \\
\hline Biaya Pemeliharaan Instalasi & $\mathrm{Rp}$ & 595.000 .000 & $\mathrm{Rp}$ & 300.606 .550 & 50,52 \\
\hline Baya Pemeliharaan Jaringan & $\mathrm{Rp}$ & 415.300 .000 & $\mathrm{Rp}$ & 118.005 .895 & 28,41 \\
\hline Biaya Pemeliharaan IPAL & $\mathrm{Rp}$ & 150.000 .000 & $\mathrm{Rp}$ & 63.929 .174 & 42,62 \\
\hline $\begin{array}{l}\text { Biaya Pemeliharaan Rutin/Berkala } \\
\text { Gedung Kantor }\end{array}$ & $\mathrm{Rp}$ & 1.250 .000 .000 & $\mathrm{Rp}$ & 617.825 .662 & 49,43 \\
\hline BM Mesin Pompa Air & $\mathrm{Rp}$ & 50.000 .000 & $\mathrm{Rp}$ & 27.317 .762 & 54,64 \\
\hline $\begin{array}{l}\text { BM Pengolahan Sampah/Rehabilitas } \\
\text { Incenerator }\end{array}$ & $\mathrm{Rp}$ & 500.000 .000 & - & & - \\
\hline BM Jaringan Pipa Gas Transmisi & $\mathrm{Rp}$ & 88.000 .000 & - & & - \\
\hline
\end{tabular}

Sumber: RSUD Bahteramas Provinsi Sulawesi Tenggara, 2018

Dari tabel di atas Rumah Sakit Umum Daerah (RSUD) Bahteramas telah mengeluarkan biaya-biaya lingkungan diantaranya pengelolaan limbah cair maupun limbah padat yang di catat pada laporan realisasi anggaran dengan jumlah anggaran sebesar Rp 9.376.100.000 dengan tingkat presentase 1,45\% dari jumlah realisasi anggaran sebesar Rp 6.452.689.752.

Adapun tujuan dalam penelitian ini adalah Untuk mengetahui perlakuan akuntansi lingkungan dan kesesuaian antara PSAP No. 1 Tahun 2010 Tentang Penyajian Laporan Keuangan dengan proses Pengidentifikasian, Pengakuan, Pengukuran, Penyajian dan Pengungkapan Biaya Lingkungan di RSUD Bahteramas serta untuk mengetahui 
pelaksanaan tanggung jawab sosial oleh di RSUD Bahteramas terkait dengan pengelolaan limbah.

\section{Pengertian Akuntansi Lingkungan}

\section{TINJAUAN PUSTAKA}

Menurut Badan Perlindungan Lingkungan Amerika Serikat (US EPA) akuntansi lingkungan adalah suatu fungsi penting untuk menggambarkan biaya-biaya lingkungan supaya diperhatikan oleh para stakeholders perusahaan yang mampu mendorong dalam pengidentifikasian cara-cara mengurangi atau menghindari biaya-biaya ketika pada waktu yang bersamaan sedang memperbaiki kualitas lingkungan. Badan Perlindungan Lingkungan Amerika Serikat (US EPA) menambahkan istilah akuntansi lingkungan menjadi dua dimensi utama. Pertama, akuntansi lingkungan merupakan biaya yang secara langsung berdampak pada perusahaan secara menyeluruh (dalam hal ini disebut dengan istilah "biaya pribadi"). Kedua, akuntansi lingkungan juga meliputi biaya-biaya individu, masyarakat maupun lingkungan suatu perusahaan yang tidak dapat dipertanggung jawabkan.

\section{Tujuan Akuntansi Lingkungan}

Tujuan akuntansi lingkungan itu sendiri adalah untuk meningkatkan jumlah informasi relevan yang dibuat bagi mereka yang memerlukan atau dapat menggunakannya. Tujuan lain dari pengungkapan akuntansi lingkungan berkaitan dengan kegiatan konservasi lingkungan oleh perusahaan maupun organisasi lainnya yaitu mencakup kepentingan organisasi public dan perusahan-perusahaan public yang bersifat lokal. Menurut Ikhsan (2009:27) tujuan dan maksud dikembangkannya akuntansi lingkungan yaitu sebagai berikut:

a) Akuntansi lingkungan merupakan alat manajemen lingkungan,sebagai alat manajemen lingkungan. Akuntansi lingkungan digunakan untuk menilai keefektifan kegiatan konservasi lingkungan. Data akuntansi lingkungan juga digunakan untuk menentukan biaya fasilitas pengelolaan lingkungan, biaya keseluruhan konservasi lingkungan dan juga investasi yang diperlukan untuk kegiatan pengelolaan lingkungan.

b) Akuntansi lingkungan sebagai alat komunikasi dengan masyarakat, sebagai alat komunikasi publik, akuntansi lingkungan digunakan untuk menyampaikan dampak negatif lingkungan, kegiatan konservasi lingkungan dan hasilnya kepada publik. Tanggapan dan pandangan masyarakat digunakan sebagai umpan balik untuk mengubah pendekatan perusahaan dalam pelestarian atau pengelolaan lingkungan.

\section{Manfaat Akuntansi Lingkungan}

Pengambilan keputusan organisasi dapat menggunakan arus informasi fisik dan informasi biaya yang disediakan oleh akuntansi manajemen lingkungan dalam membuat keputusan- keputusan yang berdampak pada kinerja keuangan dan lingkungan organisasi. Penting untuk dicatat bahwa, ketika akuntansi manajemen lingkungan mendukung pengambilan keputusan internal, penerapan akuntansi lingkungan tidak menjamin setiap tingkat kinerja keuangan atau lingkungan tertentu.Bagaimanapun juga, karena organisasiorganisasi dan program-program mempunyai sasaran tentang pengecilan biayabiaya, terutama biaya-biaya lingkungan yang memperkecil dampak lingkungan, akuntansi manajemen lingkungan menyediakan satu himpunan penting informasi untuk mencapaitujuan.

\section{Akuntansi Biaya Lingkungan}

Menurut Hamsen dan Mowen (2005) biaya lingkungan dapat diajukan sebagai biaya kualitas lingkungan. Biaya lingkungan adalah biaya yang terjadi karena terjadinya kualitas 
lingkungan yang rendah atau karena kemungkinan terjadinya kualitas lingkungan yang rendah. Biaya lingkungan mencakup baik biaya internal (berhubungan dengan pengurangan proses produksi untuk mengurangi dampak lingkungan) maupun eksternal berhubungan dengan perbaikan kerusakan akibat limbah yang ditimbulkan (Susenohaji, 2002).

Biaya-biaya yang terdapat dalam akuntansi biaya lingkungan:

1. Biaya pemeliharaan dan penggantian dampak akibat limbah dan gas buangan (waste and emission treatment), yaitu biaya yang dikeluarkan untuk memelihara, memperbaiki, mengganti kerusakan lingkungan yang diakibatkan oleh limbah perusahaan.

2. Biaya pencegahan dan pengelolaan lingkungan (prevention and environmental management) adalah biaya yang dikeluarkan untuk mencegah dan mengelola limbah untuk menghindari kerusakan lingkungan.

3. Biaya pembelian bahan untuk bukan hasil produksi (material purchase value of nonproduct) merupakan biaya yang dikeluarkan untuk membeli bahan yang bukan hasil produksi dalam rangka pencegahan dan pengurangan dampak limbah dari bahan baku produksi.

4. Biaya pengelolaan untuk produk (processing cost of non-product output) ialah biaya yang dikeluarkan perusahaan untuk pengolahan bahan yang bukan hasil produk.

5. Penghematan biaya lingkungan (environmental revenue) merupakan penghematan biaya atau penambahan penghasilan perusahaan sebgai akibat dari pengelolaan lingkungan.

Berhubung penelitian ini obyeknya adalah rumah sakit pemerintahan maka dari itu, penulis mengacu pada PSAP. Bagaimana yang sudah ditentukan dalam Pernyataan Standar Akuntansi Pemerintahan (PSAP) No. 1 tahun 2010 (Hadi, 2012:37), antara lain sebagai berikut :

1. Pengidentifikasian

Berdasarkan klasifikasi atas biaya lingkungan oleh Hansen \& Mowen, maka biaya lingkungan dibagi ke dalam empat kategori yaitu :
a. Biaya pencegahan lingkungan
b. Biaya deteksi lingkungan
c. Biaya kegagalan internal lingkungan.
d. Biaya kegagalan eksternal lingkungan.

2. Pengakuan.

Menurut Kerangka Dasar Penyusunan dan Penyajian Laporan Keuangan, pengakuan merupakan suatu proses pembentukan suatu pos yang memenuhi definisi unsure serta criteria pengakuan yang dikemukakan dalam neraca atau laporan laba rugi.

3. Pengukuran

Menurut Kerangka Dasar Penyusunan dan Penyajian Laporan Keuangan, pengukuran adalah proses penetapan jumlah uang untuk mengakui dan memasukkan setiap unsure laporan keuangan dalam neraca dan laporan laba rugi. Proses ini menyangkut dasar pengukuran tertentu. Berdasarkan hasil pengamatan, pengukuran biayalingkungan oleh rumahsakit menggunakan nilai historis.

4. Penyajian.

Menurut Suwardjono (2005):

Penyajian menetapkan tentang cara-cara melaporkan elemen atau pos dalam seperangkat laporan keuangan agar elemen atau pos tersebut cukup elemen atau pos tersebut cukup informatif, standar akuntansi biasanya memuat ketentuan tentang apakah suatu informasi objek harus disajikan secara terpisah dari laporan utama, apakah suatu informasi harus disajikan digabung dengan akun laporan keuangan yang lain, apakah 
suatu pos perlu dirinci, atau apakah suatu informasi cukup disajikan dalam bentuk catatan kaki.

5. Pengungkapan.

Pengungkapan dalam akuntansi lingkungan merupakan jenis pengungkapan sukarela. Pengungkapan akuntansi lingkungan merupakan pengungkapan informasi data akuntansi lingkungan dari sudut pandang fungsi internal akuntansi lingkungan itu sendiri, yaitu berupa laporan akuntansi lingkungan.Laporan tersebut harus didasarkan pada situasi actual pada suatu perusahaan atau organisasi lainnya. Data aktual diungkapkan ditentukan oleh perusahaan sendiri atau organisasi lainnya. Oleh karena itu diperlukan ketika pengungkapan data eksternal akuntansi.lingkungan untuk mengklarifikasi prasarat dari pengungkapan data, supaya stakeholders memperoleh pemahaman konsistensi dari data akuntansi lingkungan.

\section{Corporate Socila Responsibility (CSR)}

Corporate Social Responsibility (CSR) didefinisikan sebagai tanggung jawab sosial suatu perusahaan kepada para stakeholders, terutama komunitas atau masyarakat di sekitar wilayah kerja operasinya (Hamdani, 2016: 170). Penerapan CSR di perusahaan, khususnya rumah sakit akan menciptakan suatu hubungan harmonis antara perusahaan dan masyarakat. Salah satu tanggung jawab sosial perusahaan yang dikemukakan oleh Elkington di atas adalah dengan menjaga kelestarian alam ataupun lingkungan. Apabila rumah sakit menerapkan akuntansi lingkungan dalam kegiatan operasinya, artinya juga secara tidak langsung rumah sakit telah menjalankan Corporate Social Responsibility (CSR) dengan baik. Kedisiplinan tersebut dapat dilihat dari pengungkapan segala kegiatan yang berhubungan dengan pengelolaan lingkungan melalui akuntansi lingkungan.

\section{Jenis Limbah Rumah Sakit}

Limbah layanan kesehatan menurut Permenkes No 1204/MENKES/ SK/X/2004 tentang Pesyaratan Kesehatan Lingkungan Rumah Sakit jenis limbah yang dihasilkan. Berikut ini adalah pengertian dari berbagai jenis limbah yaitu:

a. Limbah medis padat

Adalah limbah padat yang terdiri dari limbah infeksius, limbah patologi, limbah benda tajam, limbah farmasi, limbah sitoktosis, limbah kimiawi, limbah radioaktif, limbah kontainer bertekanan, dan limbah dengan kandungan logam berat yang tinggi.

b. Limbah non medis padat

Yaitu limbah padat yang dihasilkan dari kegiatan di rumah sakit di luar medis yang berasal dari dapur, perkantoran, taman dan halaman yang dapat dimanfaatkan kembali apabila ada teknologinya.

c. Limbah Cair

Adalah semua air buangan termasuk tinja yang berasal dari kegiatan rumah sakit yang kemungkinan mengandung mikroorganisme, bahan kimia dan radioaktif yang berbahaya bagi kesehatan.

d. Limbah Gas

Adalah limbah yang berbentuk gas yang berasal dari kegiatan pembakaran di rumah sakit sepeti hasil dari incinerator, dapur masak, perlengkapan generator, anastesi dan pembuatan obat citotoksik.

e. Limbah infeksius

Adalah limbah yang terkontaminasi organism pathogen yang tidak secara rutin ada dilingkungan dan organism tersebut dalam jumlah dan virulensi yang cukup untuk menularkan penyakit pada manusia yang rentan. 
f. Limbah sangat infeksius

Yakni limbah berasal dari pembiakan dan stok bahan yang sangat infeksius, otopsi, organ binatang percobaan dan bahan lain yang telah diinokulasi, terinfeksi atau kontak dengan bahan yang sangat infeksius.

g. Limbah sitotoksis

Adalah limbah dari bahan yang terkontaminasi dari persi apan dan pemberian obat sitotoksik untuk kemoterapi kanker yang mempunyai kemampuan untuk membunuh atau menghambat pertumbuhan sel hidup.

\section{METODE PENELITIAN}

Penelitian ini dilakukan di Rumah Sakita Umum Daerah (RSUD) Bahteramas Provinsi Sulawesi Tenggara yang bertempat di Jalan Kapten Pierre Tandean No.50 Kecamatan Baruga Kota Kendari. Objek dalam penelitian ini adalah masalah pengelolaan limbah dan pengalokasian biaya lingkungan tersebut.Sumber data yang digunakan dalam penelitian ini menggunakan data primer dan data sekunder. Data primer diperoleh melalui wawancara dengan pejabat maupun pegawai yang Pegawai yang paham terkait pengelolahan limbah dan pengalokasian biaya lingkungan tersebut sedangkan data sekunder berasal dari Laporan Data sekunder dalam penelitian ini adalah data laporan keuangan, dan RBA (Rancangan Bisnis dan Anggaran) terkait biaya lingkungan RSUD Bahteramas Provinsi Sulawesi Tenggara, serta data yang diperoleh dari literatur, penelitian terdahulu,dan buku.

Metode Analisis data yang digunakan dalam penelitian ini yaitu teknik analisis deskriptif. Analisis deskriptif adalah analisis yang digunakan untuk menganalisa data dengan cara mendeskripsikan atau menggambarkan data yang telah terkumpul. Proses analisis data yang dilakukan dalam penelitian ini yaitu dengan cara mengumpulkan data berupa dokumen arsip, dan hasil wawancara atau observasi kemudian Pengidentifikasian dan Menganalisis biaya lingkungan berdasarkan laporan realisasi anggaran tahun 2018, serta Menganalisis bagaimana pelaksanaan tanggung jawab lingkungan oleh RSUD Bahteramas terkait dengan pengelolahan limbah

\section{HASIL DAN PEMBAHASAN}

\section{Hasil Penelitian}

\section{Perlakuan Biaya Lingkungan pada Rumah Sakit Umum Daerah (RSUD) Bahteramas}

Tahap tahap pelaporan akuntansi memiliki kaitan yang erat terhadap perjalanan sebuah rekening untuk diakui dan diungkapkan dalam laporan keuangan. Akuntansi lingkungan sebagai metode untuk mengungkap dan menyajikan perlakuan biaya yang berhubungan dengan pengelolaan lingkungan memerlukan tahap-tahap yang berurutan dan rinci dengan tetap mengacu pada standar akuntansi maupun pernyataan akuntansi yang berlaku umum. Tahap-tahap akuntansi ini meliputi identifikasi, pengakuan, pengukuran, penyajian, dan pengungkapan. Berikut ini merupakan tahap perlakuan akuntansi lingkungan Badan Rumah Sakit Umum Daerah (BRSUD) Tabanan yang diperbandingkan dengan teori dan prinsip yang berlaku umum:

1. Pengidentifikasian

RSUD Bahteramas mengidentifikasi biaya-biaya sehubungan dengan pengelolaan lingkungan sebagai bagian beban barang dan jasa, beban pemeliharaan dan belanja modal pada laporan realisasi anggaran. Penelusuran biaya lingkungan yang terjadi dalam RSUD Bahteramas dilakukan dengan mengamati anggaran biaya RSUD Bahteramas tahun 2018, rincian belanja RSUD Bahteramas tahun 2018 serta dengan melakukan wawancara dengan Kepala Urusan Keuangan dan Akuntansi RSUD 
Bahteramas. Setelah memperoleh informasi mengenai biaya lingkungan dan dilakukan perbandingan dengan teori pembagian biaya lingkungan menurut Hansen dan Mowen (2005), maka biaya lingkungan yang terjadi pada RSUD Bahteramas tahun 2018 dapat diklasifikasikan sebagai berikut:

a. Biaya pencegahan lingkungan. Pada tahun 2018 RSUD Bahteramas telah mengeluarkan biaya pencegahan lingkungan. Pada tahun 2018 biaya pencegahan lingkungan yang dikeluarkan RSUD Bahteramas sebesar Rp 2.398.067.878.

b. Biaya deteksi lingkungan. Biaya deteksi lingkungan terdiri dari biaya pemeriksaan penunjang luar rumah sakit dan biaya pemeriksaan baku mutu air. Jadi biaya deteksi lingkungan yang dikeluarkan RSUD Bahteramas untuk biaya pemeriksaan penunjang luar rumah sakit Rp 386.978.000, sedangkan biaya pemeriksaan baku mutu air sebesar Rp 9.730.000 dari biaya operasional.

c. Biaya kegagalan internal lingkungan terdiri dari Biaya Pemeliharaan Rutin/Berkala Gedung Kantor, Biaya Pemeliharan Instalasi, Biaya Pemeliharan Jaringan, Biaya Pemeliharaan IPAL, Biaya Pemeliharaan Jalan, Biaya Pemeliharaan AC, Biaya Cleaning Service, Biaya Pengangkutan Sampah, Biaya Pemusnahan Limbah Infeksius. Jumlah keseluruhan biaya kegagalan internal lingkungan yang dikeluarkan RSUD Bahteramas sebesar Rp 4.753.675.374 dari biaya operasional.

d. Biaya kegagalan ekternal lingkungan. RSUD Bahteramas tidak mengeluarkan biaya kegagalan ekternal karena rumah sakit tidak pernah membuang limbah ke luar lingkungan yang menyebabkan kerugian pada masyarakat lingkungan sekitar.

2. Pengakuan

RSUD Bahteramas mengakui biaya pada saat sudah memberikan manfaat meskipun kas belum dikeluarkan. Berdasarkan catatan atas laporan keuangan RSUD Bahteramas biaya lingkungan dicatat sebagai beban barang dan jasa, beban pemeliharaan dan belanja modal dalam laporan operasional dan laporan realisasi anggaran RSUD Bahteramas dan belanja modal yang terdiri dari biaya pemrolehan IPAL dan Mesin Pompa Air dicatat sebagai aset tetap dalam Laporan Keuangan RSUD Bahteramas.

3. Pengukuran

Berdasarkan hasil pengamatan RSUD Bahteramas dalam mengukur dan menilai biaya yang dikeluarkan menggunakan satuan moneter rupiah dengan acuan realisasi biaya pada periode sebelumnya dan sebesar kos yang dikeluarkan. RSUD Bahteramas memiliki alat pengelolaan limbah yaitu IPAL dan Mesin Pompa Air yang disajikan sebagai aset tetap dalam laporan posisi keuangan. Aset tetap disajikan sebesar harga perolehan dikurangi akumulasi penyusutan, penyusutan dihitung sejak bulan aset yang bersangkutan digunakan, dengan metode garis lurus berdasarkan taksiran masa manfaatnya dengan persentase tahunan dari biaya perolehan.

.4. Penyajian

Berdasarkan hasil pengamatan atas penyajian biaya lingkungan, rumah sakit menyajikan biaya lingkungan bersama dengan biaya operasional dalam laporan keuangan RSUD Bahteramas. Biaya lingkungan secara umum disajikan dalam beban barang dan jasa, beban pemeliharaan dan belanja modal dalam laporan operasional dan laporan realisasi anggaran RSUD Bahteramas dan belanja modal yang terdiri dari biaya pemerolehan IPAL dan Mesin Pompa Air dicatat sebagai aset tetap dalam laporan posisi keuangan RSUD Bahteramas. Tidak ada penyajian secara khusus pada biaya-biaya yang berhubungan dengan pengolahan limbah RSUD Bahteramas.

5. Pengungkapan

RSUD Bahteramas dalam biaya lingkungan merupakan jenis pengungkapan sukarela. Pengungkapan akuntansi lingkungan merupakan pengungkapan informasi data 
akuntansi lingkungan dari sudut pandang fungsi internal akuntansi itu sendiri, yaitu laporan akuntansi lingkungan. Penyajian dalam laporan keuangan dilakukan dengan menggabungkan beban barang dan jasa, beban pemeliharaan dan belanja modal yang digolongkan ke dalam akun belanja operasional. Pengungkapannya biaya lingkungan masuk ke dalam catatan atas laporan keuangan RSUD Bahteramas dan belum memiliki akun khusus atau laporan khusus biaya lingkungan yang terkait dengan pengelolaan limbah rumah sakit. Pengungkapan biaya lingkungan RSUD Bahteramas dalam laporan keuangan yaitu pada neraca dan laporan realisasi anggaran.

\section{Proses Pengelolaan Limbah pada Rumah Sakit Umum Daerah (RSUD) Bahteramas} Metode pengelolaan limbah Rumah Sakit Umum Daerah (RSUD) Bahteramas yaitu:

1. Metode Pengelolaan Limbah Padat Medis

Pengelolaan limbah padat medis RSUD Bahteramas dilakukan dalam 3 langkah pengelolaan. Adapun langkah-langkah pengelolaan limbah padat medis sebagai berikut:

a. Pengumpulan

Semua jenis limbah medis dibuang pada tempat sampah berupa ember plastik berwarna kuning tertutup yang telah dialasi dengan kantong plastik warna kuning, khusus limbah medis infeksius, dan limbah medis tajam (jarum, ampul, benda-benda tajam) yang di simpan di dalam safetybox yang telah tersedia di setiap poliklinik ruangan. Kegiatan pengumpulan limbah medis dilaksanakan setiap hari oleh patugas pengangkut sampah medis khusus di setiap ruangan penghasil limbah medis.

b. Pengangkutan

Limbah di angkut setelah kantong terisi limbah setiap hari/kurang sehari apabila $2 / 3$ telah terisi. Pengangkutan dilakukan setiap pagi hari pada pukul 06.00-09.00 dan sore hari pada pukul 15.00-18.00 oleh petugas khusus limbah medis dengan menggunakan kereta sampah.

c. Penyimpanan

Penyimpanan limbah medis di letakan pada ruangan yang terpisah dari badan induk rumah sakit atau memiliki ruangan khusus yang tidak jauh dari rumah sakit, dengan tembok semi permanen, dengan tujuan agar angin dapat masuk ke dalam sehingga tidak menyebabkan bau busuk dari semua jenis sampah, setelah itu baru nantinya akan diangkut oleh pihak ketiga untuk diangkut dan di bawah ke tempat pengelolaan limbah B3.

2. Metode Pengelolaan Limbah Padat Non Medis

Pengelolaan limbah padat non medis Rumah Sakit Umum Daerah (RSUD) Bahteramas ada 2 langkah yang dilakukan adalah sebagai berikut:

a. Pengumpulan

Sampah yang dihasilkan setiap ruangan yang telah dikumpulkan pada tempat sampah yang dialasi dengan kantong plastik berwarna hitam. Sampah yang telah dikumpulkan akan dibuang sementara di TPS non medis.

b. Pengangkutan ke TPA

Pengangkutan ke TPA dilakukan oleh PT. Mitra Hijau Asia cabang Kota Kendari yang akan di buang JL. TPA Puuwatu, Kecamatan Puuwatu Kota Kendari.

3. Metode Pengelolaan Limbah Cair

Limbah cair yang dihasilkan tiap unit pelayanan/gedung di tampung terlebih dahulu menggunakan septic tank, dari septic tank di alirkan melalui bakcontrol dengan menggunakan mesin pendorong yang kemudian akan di salurkan ke IPAL. Pihak rumah sakit melakukan pemeriksaan kualitas air hasil pengolahan secara bertahap 1 bulan 
sekali. Air hasil pengolahan IPAL juga ditampung di dalam kolam ikan. Apabila ikanikan dalam kolam tetap hidup, maka dapat dipastikan air hasil olahan IPAL tersebut tidak mengandung zat berbahaya sehingga dapat digunakan lagi untuk keperluan lain seperti menyiram tanaman di lingkungan rumah sakit.

4. Metode Pengelolaan Limbah Gas

Pihak RSUD Bahteramas belum melakukan pengelolaan terkait limbah gas yang dihasilkan oleh pihak rumah sakit.

\section{Pembahasan}

\section{Perlakuan Biaya Lingkungan pada Rumah Sakit Umum Daerah (RSUD) Bahteramas}

Berdasarkan hasil penelitian yang telah dilakukan diketahui bahwa Rumah Sakit Umum Daerah (RSUD) Bahteramas dalam mencatat akuntansi lingkungannya, diakui sebagai komponen beban barang dan jasa, beban pemeliharaan dan belanja modal yang digolongkan ke dalam akun belanja operasional. Rumah Sakit dalam mengukur dan menilai biaya-biaya lingkungan yang dikeluarkan menggunakan satuan moneter rupiah dengan acuan realisasi biaya pada periode sebelumnya, menyajikan biaya lingkungannya dalam kelompok biaya operasional rumah sakit di dalam sub sub unit yang sejenis dalam laporan realisasi anggaran. RSUD Bahteramas belum melaporkan dan menyajikan biaya lingkungan dalam laporan secara khusus akan tetapi RSUD Bahteramas sudah melakukan pelaporan atas kegiatan pengelolaan lingkungannya pada laporan keuangan mereka.

\section{Pelaksanaan Tanggung Jawab Sosial oleh RSUD Bahteramas Terkait Pengelolaan Limbah}

Rumah Sakit Umum Daerah (RSUD) Bahteramas termasuk salah satunya organisasi yang kegiatan operasionalnya berpotensi menghasilkan limbah terlebih limbah tersebut adalah limbah yang berbahaya. Tentunya jika limbah tersebut di buang begitu saja tanpa di kelola maka akan dapat membahayakan lingkungan di sekitar terlebih makhluk hidupnya. Mengacu pada Undang-Undang No. 32 Tahun 2009 tentang perlindungan dan pengelolahan lingkungan hidup, dan Undang-Undang No. 25 Tahun 2007 tentang penanaman modal. Dimana pada dua Undang-Undang tersebut mengatur akan kewajiban orang yang melakukan usaha hendaknya melakukan pengelolaan limbah hasil usahanya.

Berdasarkan hasil penelitian pihak RSUD Bahteramas telah melakukan tanggung jawabnya sebagai perusahaan yang menghasilkan limbah, baik itu limbah medis maupun limbah non medis. Berdasarkan hasil wawancara dari warga yang tinggal di lingkungan sekitar, dapat disimpulkan bahwa pihak RSUD Bahteramas sudah mengelola limbahnya dengan baik sehingga yang awalnya limbah tersebut berbahaya yang kemudian dikelola dengan baik sehingga menjadi limbah yang aman bagi lingkungan di sekitarnya.

\section{Kesimpulan}

\section{KESIMPULAN DAN SARAN}

Berdasarkan hasil analisis data dan pembahasan yang telah dilakukan di RSUD Bahteramas Provinsi Sulawesi Tenggara, maka dapat disimpulkan sebagai berikut :

1. Rumah Sakit Umum Daerah (RSUD) Bahteramas sudah menerapkan akuntansi biaya lingkungannya. Biaya lingkungan tersebut dimasukkan pada biaya beban barang dan jasa, beban pemeliharaan dan belanja modal yang digolongkan ke dalam akun belanja operasional. Namun rumah sakit belum menyajikan laporan khusus mengenai akuntansi lingkungannya secara lebih rinci.

2. RSUD Bahteramas sudah melakukan proses Pengidentifikasian, Pengakuan, Pengukuran, Penyajian, dan juga Pengungkapan seperti yang sudah dijelaskan pada Standar Akuntansi Pemerintahan per 13 Juni 2010. SAP No.1 menjelaskan tentang penyajian laporan keuangan. Dimana RSUD Bahteramas mengakui biaya lingkungan 
pada saat sudah mendapat manfaat dari hal tersebut meskipun kas belum dikeluarkan, pengukuran biaya lingkungan dengan satuan moneter rupiah yang mengacu pada realisasi biaya periode sebelumnya sebesar kos yang dikeluarkan. Biaya lingkungan disajikan dengan memasukkan komponen-komponen biaya lingkungan pada laporan keuangan umum dan diungkapkan secara keseluruhan dalam laporan keuangan RSUD Bahteramas pada biaya-biaya sejenis seperti beban barang dan jasa, beban pemeliharaan dan belanja modal dalam laporan operasional dan laporan realisasi anggaran RSUD Bahteramas dan sebagai bagian dari aset tetap dalam neraca.

3. RSUD Bahteramas sudah melakukan pengelolaan limbah mereka dengan baik. Limbah yang dihasilkan dari kegiatan operasional rumah sakit berupa limbah padat dan cair. Pengelolaan limbah cair yang dilakukan Rumah Sakit Umum Daerah (RSUD) Bahteramas dengan menggunakan Instalasi Pengolahan Air Limbah (IPAL) sedangkan untuk pengelolaan limbah padatanya sendiri pihak RSUD Bahteramas bekerja sama dengan PT. Mitra Asia Hijau Cabang Kendari.

\section{Implikasi}

Berdasarkan hasil penelitian dan pembahasan, menunjukkan bahwa pengungkapan akuntansi lingkungan di RSUD Bahteramas sudah menerapkan akuntansi biaya lingkungan, namun rumah sakit belum menyajikan laporan khusus mengenai akuntansi lingkungannya secara lebih rinci. Pihak rumah sakit belum menyadari arti penting akuntansi lingkungan yang dapat memberikan manfaat yang signifikan dalam jangka pendek, tetapi dapat memberikan manfaat yang besar dalam jangka panjang. Salah satunya dengan menghasilkan rincian pengalokasian biaya lingkungan yang di perlukan serta menambah informasi yang relevan untuk para pemangku kepentingan. Diharapkan dengan adanya akuntansi lingkungan perusahaan bisa memperbaiki kinerja lingkungan perusahaan yang selama ini mempunyai dampak negatif terhadap kesehatan manusia yang berada di sekitar perusahaan dan keberhasilan bisnis perusahaan.

\section{Keterbatasan Penelitian}

Penelitian ini hanya memfokuskan mengenai pengklasifikasian, pengakuan, pengukuran, penyajian dan pengungkapan akuntansi lingkungan di RSUD bahteramas serta bagaimana tanggung jawab sosial perusahaan terhadap lingkungan sekitar. Pihak perusahaan belum menyajikan laporan khusus mengenai akuntansi lingkungannya secara lebih rinci sehingga peneliti harus mengklasifikasikan biaya lingkungan sendiri. Peneliti selanjutnya hendaknya meneliti perusahaan lain yang memiliki dampak negatif yang besar akibat dari kegiatan operasional perusahaan dan bagaimana dampak kinerjanya terhadap masyarakat sekitar

\section{Rekomendasi}

Bagi pihak RSUD Bahteramas apabila ingin meningkatkan penerapan akuntansi lingkungan dengan lebih baik lagi, rumah sakit harus segera membuatkan laporan khusus terkait biayabiaya yang berhubungan dengan lingkungan dengan lebih terperinci sebagai bentuk tanggungjawab terhadap lingkungan. Laporan biaya lingkungan tersebut akan menjadi suatu motivasi bagi pihak manajemen dalam meningkatkan efektivitas dan efisiensi pengolahan limbah serta menjadi nilai tambah (value added) tersendiri bagi rumah sakit.

\section{DAFTAR PUSTAKA}

Andika, Ayu. 2017, Analisis Perlakuan Akuntansi Atas Biaya Pengolahan Limbah Pabrik (Studi Penerapan Akuntansi Lingkungan Pada Pt Indo Citra Jaya Samudra Jembrana). Jurnal Riset Akuntansi. Vol. 8. No 2

Carolina, Verani dan Riki Martusa. 2009. "Akuntansi Lingkungan : Solusi untuk Problematika Penerapan Corporate Social Responsibility di Indonesia”. Prosiding Seminar Nasional Problematika Hukum dalam Implementasi Bisnis dan Investasi. 
Jurnal Akuntansi dan Keuangan (JAK)

Volume 6, No. 1 Februari Tahun 2021

Page: $307-318$

http://ojs.uho.ac.id/index.php/jak-uho/issue/archive

e-ISSN: 2088-4656

Depkes Republik Indonesia. Permenkes Nomor 340/Menkes/Per/III/2010, Tentang Klasifikasi Rumah Sakit, 2010.

Depkes Republik Indonesia. Permenkes Nomor 1204/MENKES/SK/X/2004 Tentang Persyaratan Kesehatan Lingkungan Rumah Sakit. Jakarta

Hadi, Shofyan, 2012. Analisis Penerapan Akuntansi Lingkungan Pada Pt. Istana Cipta Sembada Banyuwangi. Skripsi. Fakultas Ekonomi Universitas Jember.

Hamdani. 2016. Good Corporate Governance: Tinjauan Etika dalam Praktik Bisnis. Mitra Wacana Media.

Hansen, R dan M. Mowen. 2005. "Management Accounting".7th Edition. Diterjemahkan oleh Dewi Fitriasari dan Deny Arnos Kwary. Jakarta: Salemba Empat.

Ikhsan, Arfan. 2008. Akuntansi Lingkungan Dan Pengungkapanya. Yogyakarta: Graha Ilmu.

2009. Akuntansi Manajemen Lingkungan. Yogyakarta: Graha Ilmu.

Peraturan Pemerintah Nomor 27 Tahun 1999 Pasal 1ayat 1 Tentang Analisis Mengenai Dampak Lingkungan Hidup (AMDAL). Jakarta.

Pernyataan Standar Akuntansi Keuangan Nomor 33 Tahun 2014 Tentang Penyertaan biaya-biaya lain seperti biaya lingkungan.

Pernyataan Standar Akuntansi Pemerintahan Nomor 1 Tahun 2010 Tentang Penyajian Laporan Keuangan.

Susenohaji. 2002. Environmental Management Accounting (EMA) : Memposisikan Kembali Biaya Lingkungan Sebagai Informasi Strategis bagi Manajemen.

Suwardjono. 2005. Teori Akuntansi : Perekayasaaan Pelaporan Keuangan. Edisi III. Yogyakarta : BPFE.

Undang-Undang Republik Indonesia Nomor 23 Tahun 1997 Tentang Pengelolahan Lingkungan Hidup. Jakarta.

Undang-Undang Republik Indonesia Nomor 32 Tahun 2009 Tentang Perlindungan dan Pengelolaan Lingkungan Hidup. 